\title{
Research on Computer Basic Teaching Reform under the Big Data Thinking Mode in Colleges and Universities
}

\author{
Rujuan Wang \\ College of Humanities \& Sciences of Northeast Normal \\ University \\ Changchun 130012, China \\ wangrujuan_1108@sina.com
}

\author{
Xin Sui* \\ College of Humanities \& Sciences of Northeast Normal \\ University \\ Changchun 130012, China \\ 32329669 @qq.com
}

\begin{abstract}
The big data era is affecting all fields of human beings. It brings not only massive data, but also changes of traditional thinking patterns and behavior habits. In the field of education, especially the basic computer education in universities, it is greatly influenced by the background of this era because of its teaching content, teaching means and the characteristics of the teaching groups. Faced with this change, a thorough reform is urgently needed in basic computer teaching in Colleges and universities. This paper mainly discusses the current problems faced by basic computer teaching, puts forward the reform ideas of basic computer teaching under the big data thinking, and implements the teaching reform.
\end{abstract}

Keywords-Big Data; Thinking Mode; Teaching Reform; computer teaching

\section{INTRODUCTION}

With the opening the big data era, the types of data we come into contact with are becoming larger. As the masters of the future society, college students need to master certain data analysis and processing capabilities to adapt the development. Schools also need to adjust their talent training plans in a timely manner. The teaching content should change with the times. It is the key content of computer education reform to cultivate professionals with strong innovative consciousness and comprehensive ability. Only by keeping pace with the times can we achieve the goal of education and cultivation and provide high-end employment talents for enterprises. As a compulsory course for college students, the course of Computer Foundation in College has a certain impact on the level of computer knowledge of College students [1][2]. The development of the times has put forward higher requirements for the society, and the reform of basic computer courses is also imminent. The arrival of the big data era is a new challenge to teaching research. Whether it is the design of content or the innovation of teaching methods, it is a major change in computer teaching [3].

Big data is a large-scale data set which is far beyond the capability of traditional database software tools in terms of acquisition, storage, management and analysis. It has four characteristics: massive data scale, rapid data flow, diverse data types and low value density. The strategic significance of big data technology lies not in mastering huge data information,

Educational Science Planning in Jilin Province "13th Five-Year" No.2018-5 but in specialized processing of these meaningful data. In other words, if big data is compared to an industry, the key to making profits in this industry lies in improving the "processing ability" of data and realizing the "value-added" of data through "processing". In teaching practice, the important value of big data on the Internet lies in the target analysis and research of data to achieve the purpose of evaluating the advantages and disadvantages of traditional teaching mode, thus promoting the information of computer basic classroom teaching in Colleges and universities in China[4][5].

\section{The PRESENT SituAtion OF COMPUTER BASIC EDUCATION IN UNIVERSITIES}

As a futurist of the United States, Alvin Toffler predicted in the 1980s that information will be the dominant factor in the era after the 21st century, and that material and energy as the elements of the world will gradually be replaced by information. The human world has been completely changed by big data, especially in the way of thinking; the emergence of "big data thinking" has greatly reformed human thinking. In terms of application, this mode of thinking will be very common. There is a great possibility of its universal application in social management, public transport and security. In the future, the economy will take the Internet of Things, cloud computing and big data as growth points. From the perspective of big data thinking, the past outlook on development and value will no longer restrict people's thinking, and will have a very far-reaching impact on human life and work. Computers are developing rapidly around the center of data, and the thinking mode of big data is becoming more and more obvious. On the one hand, this thinking breaks through the past mode of thinking and promotes the leap-forward development between disciplines. On the other hand, the fixed mode of thinking formed between natural and Social Sciences in the past is broken by this thinking, which points out a new direction for the future development of human civilization and social civilization.

For the innovation and development of basic computer courses, it is inseparable from the construction of relevant theoretical system. The basic computer courses need students to have a good theoretical basis, and have a preliminary understanding of the new requirements of computer 
development and new curriculum concepts under the background of big data development, so as to better carry out the study of basic computer courses. But when the school constructs the computer network course system, it does not design and analyze the theory teaching too much, which leads to the imperfect development of the theory teaching system of the basic computer course, which is not conducive to laying a good foundation for students to study computer theory, but also affects students' learning and understanding of computer information in the era of data.

\section{THOUGHTS ON THE REFORM OF COMPUTER BASIC EDUCATION}

\section{A. Diversification of teaching methods}

Under the background of big data era, classroom learning in the past will no longer be the basic mode of human learning. The mode of learning includes offline and online, collective teaching and autonomous learning. Learning can be accomplished through teachers' explanations and their own exploration, which combines rich learning modes. With the help of online learning system, people can get more and more abundant information. Through communication with students and teachers, students must have a very clear ability to distinguish and reject a certain department.

Distribute false and bad news. The thought gradually tends to be planar. Web link is the main way of information storage in the network. Students learn information mostly on the basis of web site. Compared with the previous day-to-day learning methods, the network has changed the overall structure of knowledge, which is conducive to students' comprehensive learning of new knowledge. In addition, the application of Web site is simpler and students can remember it faster. There are so many network information data that students can learn what they want according to their needs and make their own unique ideas. However, because college students are still in the learning state, their ideas and outlook on life are not mature, and their ability to distinguish right from wrong is not strong. Therefore, educational administrators should make special management guidance for the students' thinking. Big data technology combines teaching, learning and virtual reality to realize the individualized education of computer foundation.

Building a new education model based on big data technology can greatly meet the learning requirements of different students. By using big data technology combined with software and hardware facilities, a virtual learning scene can be constructed. When students enter this scene, they will receive visual, auditory, tactile and other information, so that they can produce a more real learning environment for students. Fully mobilize students' memory cells, while keeping students' memory cells highly active and focused, the computer teaching content is imparted to students; through entering the virtual learning platform constructed by big data technology, students can real-time feedback their learning situation to the control center through virtual helmet and virtual gloves, while teachers through the control center for. Students' learning feedback information is collected and sorted out, and their teaching methods and contents are flexibly adjusted. At the same time, teachers and students can achieve good interaction on this platform. Teachers are not only the imparters of knowledge, but also the participants in teaching. Through virtual reality scenes, teachers and students can achieve good learning interaction. Using the big data technology education system, students can discuss and cooperate with teachers or classmates. Under this virtual learning environment, both teachers and students are participants in learning. Students can further consolidate their knowledge by communicating with teachers or classmates. Teachers can grasp students' learning dynamics in real time and cooperate with students to promote the development of teaching activities.

Problem-solving ability in task context: By simulating typical task, the typical situation that the task often appears in practical work is proposed. Students apply the concepts, definitions and standards they have learned before, apply the processes, tools and methods they have mastered before, formulate the solution to the problem, and form experience through role-playing, and through self-summary and analysis. In this teaching process, students can also turn back to learn the relevant knowledge points, re-analysis and practice related process tools and methods according to the typical task situation, aiming at the problems they face, so as to stimulate students to learn based on task, problem-oriented and situation, so as to achieve learning and really train their ability to solve problems.

\section{B. Enrichment of Teaching Content}

With the widening of learning materials and various forms and types of teaching materials appearing on the internet, students cannot cope with the problem of multiple choices. At the same time, the new teaching mode of computer specialty has formed a huge impact on traditional teaching. Today, with the rapid development of information network, the interference of big data on computer teaching is reflected in all aspects of teaching resources, and is not limited by time and region. Construct a "three-dimensional curriculum" textbook system which is unified with the teaching contents of various courses, including the main textbooks, teachers' books, and students' ability training books and so on. Subject textbooks are the main carriers of practical teaching content, mainly elaborating what students learn and how to learn; teacher handbooks are the carriers of teaching process design, mainly elaborating what teachers teach and how to teach; students' ability training books are the carriers of curriculum training content and teaching effect evaluation, mainly elaborating what to do and how to do. Through this three-dimensional textbook system, students' ability training standards are established, and students' comprehensive ability is tested through various ways to promote the integration of teaching and learning.

\section{Rationalization of teaching evaluation}

Under the big data technology, education emphasizes more on the cultivation of students' comprehensive quality, so when we train our education and teaching, we should not only pay attention to improving students' computer professional skills, but also pay attention to improving their practical ability, which is also the real purpose of our education [6]. Therefore, the establishment of education evaluation system is the basic demand for the evaluation of education and teaching quality. Through the establishment of network inquiry system, students at different levels are trained in basic knowledge, professional 
skills and comprehensive innovation skills. We can give timely feedback on teaching methods and contents, constantly innovate outdated computer teaching contents and add new teaching contents to improve the mastery of basic knowledge and skills according to students' mastery of basic theoretical knowledge. According to the actual teaching situation, add some computer experiment content which is experimental but not very deep. In this way, students can have a further understanding of the basic knowledge, basic experimental operation methods and basic principles used in teaching. Continuously improve students' mastery of general methods and processes as well as their ability to deal with problems.

The determination of comprehensive experimental evaluation mechanism is that students use experimental skills comprehensively to improve themselves after mastering the basic computer experimental methods and experimental principles in basic experiments. When designing the comprehensive experiment, we should fully consider the requirements of comprehensiveness and design, let students choose the content of the experiment independently, explore the scheme of the experiment independently, and carry out the experiment independently. The content chosen in the experiment should keep pace with the development of the subject, so that students can feel the latest developments of the frontier science and technology. In terms of the difficulty of the experiment, we should design the suitable experimental content according to the students' own ability, and then fully stimulate students' curiosity and professional interest. The purpose of carrying out various kinds of teaching practice activities is not only to strengthen students' mastery of computer theory knowledge, but also to enable students to discover and innovate in the process of practice. In the design of computer innovation teaching system, we should pay attention to cultivating students' comprehensive application ability of subject knowledge, and cross-penetrate different subject knowledge. In the process of innovating teaching system, we should pay attention to the requirements of students' individuality, weaken the teaching function of teachers, and improve the teaching guidance function of teachers. Continuously enrich the teaching content, will improve the practical ability as the subject requirement of the experiment. The content of the experiment should be from shallow to deep. The content of the experiment should adhere to the combination of practice and innovation, maximize the potential of innovation, and constantly cultivate students' innovative thinking ability and comprehensive skills.

\section{Application of Big Data in Teaching Process}

A complete course teaching process should be divided into three parts: pre-class preparation, course teaching and afterclass evaluation. Only when the pre-class preparation is made, can the contents and difficulties of a certain course be clearly defined; only when the course is well taught, can the students master relevant knowledge and skills in accordance with the objectives of the talent training program; only when the postclass evaluation is done, can the pre-class work be reflected, the advantages and disadvantages be summarized, and better preparation for the next step can be made. In the following three parts, this paper elaborates the application of big data technology in the field of teaching process [7].

\section{A. Pre-Class Preparation}

Everyone is unique in the world, different from others in intelligence, personality, and emotion and so on, so each person's absorption process and degree of knowledge are different. The scale effect of education promotes the birth of standardized classroom teaching. With the popularization of education in recent years, the shortcomings of standardized classroom teaching have become increasingly prominent. Moreover, modern society is a pluralistic society, which needs diversified talents. Therefore, individualized education that teaches students in accordance with their aptitude urgently needs to be returned. However, the contradiction between a large number of students and teachers caused by the popularization of education makes it difficult to teach students in accordance with their aptitude. Nowadays, if we can apply big data technology to the analysis and statistics the personal information of students, prepare different teaching methods according to each different knowledge, personality and hobbies of students, and distinguish the depth of the course content, then this kind of pre-class preparation is really effective.

\section{B. Course Teaching Process}

With the support of the big data analysis to personal information of students, teachers can make different teaching plans according to the differences of each student before class. But if the teaching process cannot be reformed, it will be difficult to complete the process of teaching according to their aptitude under the current situation of the ratio of students to teachers in Colleges and universities, because a teacher cannot speak to each student in different ways in the limited time of traditional classroom. Understand the different depth of content This requires the use of big data technology to support the course teaching process, develop and share videos of relevant professional courses in Colleges and universities. Then, through the open online learning platform, students can freely choose corresponding courses within the basic rules formulated by teachers. This not only meets the individual needs of different students, but also reforms the teaching time and place limitations of traditional teaching methods. Of course, although the online learning platform can also design some humancomputer interaction, it still cannot completely solve all kinds of puzzles in the learning process of students. Therefore, the course teaching process still needs to set a certain time to arrange face-to-face communication between teachers and students.

\section{Course Evaluation Process}

Curriculum evaluation mainly includes evaluation of students and teachers. At present, many school set the teaching evaluation of students to teachers at the end of the semester or other fixed time points, and the evaluation clauses are single and rigid. Such post-evaluation cannot play a timely role in promoting the adjustment of the teaching process, nor has it much guiding significance for the next cycle of teaching process.

Large data technology should be used to design more evaluation options and details, and at any time can be evaluated for a certain knowledge point, daily or weekly statistical analysis of the evaluation, so that teachers can adjust teaching in time to achieve good teaching results. Similarly, the 
traditional way for teachers to evaluate learning effect of students is mid-term and final examinations, which also has lagging defects. Moreover, when the content of the examination is not large enough, the evaluation results are not comprehensive. If we can make use of big data technology and change the evaluation method to process-based comprehensive evaluation, that is, to evaluate each knowledge point, and to evaluate each student comprehensively according to his or her usual learning, homework and extracurricular knowledge development, the evaluation results will be more objective and comprehensive.

\section{CONCLUSION}

The arrival of big data era is both an opportunity and a challenge, bringing new impetus to the development of computer teaching. Therefore, teachers must strengthen the practicality of teaching, improve the quality of teaching, and strengthen interaction and communication with students. At the same time, we should sum up the teaching experience, develop and innovate the teaching mode in the big data era, perfect the teaching theory system, cultivate students' abilities in many aspects, and meet the new demands of the society for talents. At the same time, teaching results should be related to the needs of enterprises. School-enterprise cooperation can provide students with a broader learning platform, thus helping schools to cultivate computer professionals that enterprises really need. This is a mutually beneficial and win-win teaching model.

Big data is an abstract concept. How to apply big data thinking to the teaching of computer foundation is an important issue of teaching reform in the new era. With the development of science and technology, the application of big data has a high ability to integrate and analyze things, and can accurately process and judge data. Therefore, the cultivation of big data talents is the need of social development and the embodiment of scientific progress. In order to find out the demand of big data market for the practical ability of talents and improve the teaching content, we should combine the particularity of computer specialty.

\section{ACKNOWLEDGMENT}

This work was partially supported by Educational Science Planning in Jilin Province "13th Five-Year" No.2018-5.

\section{REFERENCES}

[1] Tang-Tang Y I. Application of Network Resources in Computer Teaching in University[J]. Journal of Jishou University, 2010.

[2] Mavi D, Uzunboylu, Hüseyin. Content Analysis of Articles about Computer Teaching Methods: A Content Analysis Study[J]. Procedia Social and Behavioral Sciences, 2014, 143:1171-1176.

[3] Anthony K, Seth J J, Luis B. Development of a Web-Based Computer Teaching Module using Eponyms and the "Who am I?" Method to Learn Anesthesia History[J]. Journal of Anesthesia History, 2018, 4(1):24-.

[4] Fu W, Ping Y, Shuai L. Research on the Related Teaching Method of Computer Operating System Course[C]// International Conference on Elearning. 2018:292-297.

[5] Wang Q, Jiang X Q . [IEEE 2018 10th International Conference on Measuring Technology and Mechatronics Automation (ICMTMA) Changsha, China (2018.2.10-2018.2.11)] 2018 10th International Conference on Measuring Technology and Mechatronics Automation (ICMTMA) - Empirical Study on Reform Model of College English Teaching Model Based on Computer and Big Data[J]. 2018:412-415.

[6] Hermosilla P, Boye N, Roncagliolo S. Teaching Communication Strategies in Social Networks for Computer Science Students[M]// Social Computing and Social Media. User Experience and Behavior. Springer, Cham, 2018

[7] Borell, Jonas. The Role of Gender in Students' Ratings of Teaching Quality in Computer Science and Environmental Engineering.[J]. IEEE Transactions on Education, 2017, 60. 